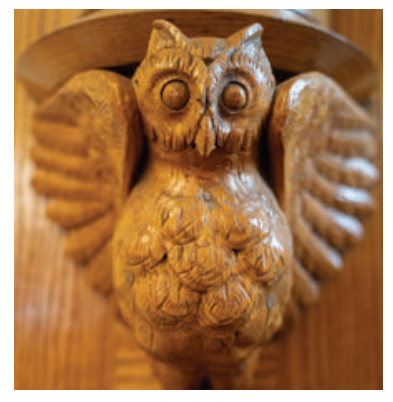

\title{
Bibliographical Note
}

The initial sources for the history of Cornell University 1 Press and Comstock Publishing were found in the Cornell University Press archives, including previously written histories. The Cornell University Library Rare and Manuscript Collection was a vital source of historical photographs, biographical files on early directors, and information on the building of Sage House. Digitized primary sources at the university and elsewhere made research a much easier task than in decades past and the following sources were invaluable: Cornell University Board of Trustees reports, annual reports of the president of Cornell University, Ithaca Daily Journal, Ithaca Journal, Cornell Alumni News, Cornell Bulletin, Cornell Chronicle, Cornell Daily Sun, Cornell Era, Cornell Magazine, Cornell Register, and Cornell Plantations magazine.

The history of Comstock Publishing is detailed in an unpublished I944 manuscript, "A Half-Century of the Comstock Publishing Company; I893-I943," by Simon Henry Gage and Clara Starrett Gage. Accounts of the early history of Cornell University Press were found in a draft chapter by Woodford Patterson for Robert Frederick Lane, "The Place of American University Presses in Publishing" (PhD diss., University of 
Chicago, 1938) and in B. Alsterlund and Walter Pilkington, "The First Real University Press in the United States," American Notes and Queries (August 1946). The best and most enjoyable source for the history of Cornell in general is always Morris Bishop's A History of Cornell (Ithaca: Cornell University Press, I962).

Roaming farther afield, sources include J. M. Hart, "Cornell University," Scribner's Monthly (May I873); John H. Selkreg, ed., Landmarks of Tompkins County (Syracuse: D. Mason \& Company, I894); Peter Givler, "University Press Publishing in the United States," http://www.aupresses.org/about-aaup/ about-university-presses/history-of-university-presses; John K. Hutchens, "One Thing and Another," Saturday Review (June 2I, I969); and Morris Bishop, "The Lower Depths of Higher Education," American Heritage 2I, I (I969).

\section{Photo Credits}

Photos of Ezra Cornell, A. D. White, Daniel Willard Fiske, Morrill Hall, George Lincoln Burr, Sibley College, John Henry Comstock, Simon Henry Gage, Anna Botsford Comstock, Lane Cooper, Woodford Patterson, Victor Reynolds, Roger Howley, David Gilbert, and John Ackerman are printed here courtesy of the Cornell University Library Rare and Manuscript Collection. Walter Lippincott, Mahinder Kingra, and Peter Potter kindly provided photos of themselves. The present-day photos of Cornell staff and of Sage House architecture are courtesy of Scott Levine. All other photos are property of the press. 